\title{
MEASURING CREDIT STRUCTURE IMPACT ON ECONOMIC GROWTH IN CROATIA USING (VECM) 1990-2018
}

\author{
Marinko ŠKARE ${ }^{\mathbb{D}^{*}}$, Dean SINKOVIĆ ${ }^{\left(\mathbb{D}_{2}\right.}$, \\ Małgorzata PORADA-ROCHON ${ }^{\left(D_{3}\right.}$ \\ 1, 2 Faculty of Economics and Tourism "Dr. Mijo Mirković", \\ Juraj Dobrila University of Pula, Pula, Croatia \\ ${ }^{3}$ Faculty of Management and Economics of Services, \\ University of Szczecin, Szczecin, Poland
}

Received 17 October 2018; accepted 21 January 2019

\begin{abstract}
Studies on the finance-growth link use different proxy variables for financial development. Among the most used is the total credit share in the GDP. Previous empirical studies show to be sensitive to the choice of the finance proxy indicator. Total credit share in the GDP appears biased in empirical modeling. Credit structure (loans to firms and households) prove to be more robust when used in the modeling. Credit structure reveals a different impact on economic growth showing lending policy impact varies depending on the credit structure. Researchers studying the finance-growth link must account for this when investigating supply leading and demand-following theories. Policymakers should also take care of the credit structure since loans to household discourage growth in the long run and are sensitive to economic shocks. We find empirical evidence to support both supply leading and demand- following theory. Bi-directional causality between private loans to firms/households and economic growth exists using Granger causality test. Private loans to firms and households economic growth exists using Granger causality test. Private loans to firms and households have a positive impact on economic growth in Croatia.
\end{abstract}

Keywords: growth, credit, Croatia, VECM, credit cycles, financial development, transition.

JEL Classification: C58, F43, H81, P24.

\section{Introduction}

There is a long going debate on the relationship between financial development and economic growth. The discussion is intense in developing and transitional economies with limited goals and instruments over the financial markets and monetary policy. Levine (2005) sets a theoretical framework explaining how financial development affects economic growth. Financial development stimulates economic growth through five channels; facilitating risk

*Corresponding author. E-mail: mskare@unipu.hr 
management, allocating resources, exerting corporate control, mobilizing savings and ease trading of goods and services, leading to capital accumulation and technological innovation and growth. Empirical studies supporting the supply-leading hypothesis and positive financial development - growth link advanced by Levine (2005) are present in King and Levine (1993a, 1993b), Beck and Levine (2004), Arestis, Demetriades and Luintel (2001), Asteriou and Spanos (2018). We can find supporters of demand-following hypothesis, economic growth cause financial development in Egbetunde and Akinlo (2015), DemirgucKunt, Detragiache, and Merrouche (2013), Fan, Xu, Su, and Shi (2017) and Stolbov (2017).

Previous studies research the impact of financial development on economic growth using proxy variables for financial development; ratio of domestic private credit to GDP (gross domestic product), ratio of M3 to nominal GDP, total credit, and interest spread, a ratio of M2 to GDP, the ratio of total bank-deposit liabilities to nominal GDP, bank-deposit money assets. This study takes a different approach to research credit structure impact on economic growth in Croatia 1990-2018. Benczúr, Karagiannis and Kvedaras (2017) study the impact of household and credits to non-financial corporations using generalized method of moments (GMM). Their results show that the finance-economic growth nexus shows non-linear properties and depend on the proxy used for financial development. While total credits show a positive impact on economic growth, credit to households shows a negative impact on growth. Private credits to non-financial corporations positively affect economic growth according to their study. Panel studies show observation for a group of countries for a limited time horizon while time series approach can reveal additional data generation process patterns. Therefore, we use VAR (vector auto-regression) and VECM (vector error correction) model to study the impact of the finance structure (bank lending) on economic growth. To study the impact of bank credits structure on economic growth, we follow an individual approach of choosing Croatia as a country case. There are several valid reasons for studying the finance structure impact on economic growth using data for Croatia; it is a former transitional country, in a last 25 years it has gone through the transition from a centrally planned financial system to financial market, it is a leveraged country, personal consumption is an important factor of GDP growth driven by household credits (since wages are among the lowest in the EU), has passed a painful privatization of the banking system in 1998 and most prolonged economic crisis in 2008.

Past research on finance and economic growth nexus did not focus on the financial structure on economic growth, except for Benczúr et al. (2017), studying developed (OECD) countries and not looking for long memory or non-linear effects. The empirical evidence still misses proving the theoretical idea behind the finance-economic growth nexus leaving the body of literature with an incomplete picture on the issue.

This research addresses these gaps in the literature, looking for a long memory pattern in the data. This research tries to encourage more country-oriented/individual studies using a time series approach. Past studies have shown that the causality link between financial development and economic growth is not robust to change in proxy variables used in the empirical models. A non-linearity and long memory issues found in previous studies demands more time series and individual studies to get a clear picture on the finance-growth link. Country economical and historical background also exhibits large influence on the finance-growth link limiting the robustness of the panel studies results on the matter. 
The paper has five parts. First, it reviews previous studies on the financial development, bank lending, and economic growth. Then in the next section we discuss research method and data analysis techniques. Findings discussion and a summary is in section four. The article concludes with discuss of the theoretical and practical implications of the study results and directions for future research.

\section{Literature review}

Schumpeter (1934) was the first to notice the relationship between financial development and economic growth and show the role of the banking system in supporting economic growth. Kuznets (1955), Patrick (1966), Goldsmith (1969), McKinnon (1973), Shaw (1973) are the pioneers of research on the relationship between financial development and economic growth nexus. After 1980, there was an increase in interest in studying these research problems from different perspectives, using different determinants and method. Although results differ, most of them confirm the positive impact of financial development on economic growth.

Topcu (2016) reviewed the literature related to finance growth nexus. Part of the presented research referred to the causality between financial development and economic growth ${ }^{1}$ investigated, by among others: Thornton (1996), Demetriades and Hussein (1996), Levine and Zervos (1998), Habibullah (1999), Arestis and Demetriades (1999), Darrat (1999), Calderon and Liu (2003), Christopoulos and Tsionas (2004), Dritsakis and Adamopouls (2004), Lee (2005), Habibullah and Eng (2006), Acaravci, Ozturk, and Kakilli Acaravci (2007), Eita and Jordaan (2010), Enisan and Olufisayo (2009), Caporale, Rault, R. Sova, and A. Sova (2009), Kilimani (2009), Esso (2010), Chimobi (2010), Hassan et al. (2011), Rachdi and Mbarek (2011), Bojanic (2012), Ray (2013), Hsueh et al. (2013).

One element of financial development affecting the economic growth is credit policy. Considering the impact of credit on economic growth, it is possible to show a dozen of the latest research results. Gómez-Puig and Sosvilla-Rivero (2018) analyzed the effects of non-financial debt on economic growth in EMU countries (10 countries) for the period 1980-2015. Results show that private debt is harmful in periphery countries. Household debt reduction may be of key importance in such countries.

Léon (2018) investigated convergence of credit structure in 143 countries during the period 1995-2014. One result show that during the period between 2000 and 2014, the growth of both household and firm credits was higher for countries with a limited level of financial development. Financial development in Turkey shows a positive impact on the firms' growth (Topcu \& Çoban, 2017).

Ibrahim and Alagidede (2018) analyzed the economic growth effects in 29 sub-Saharan African countries during the 1980-2014 period, when the growth in financial development and real sector was unbalanced. Empirical results showed that financial development hinders economic growth when the improvement in the financial sector not followed by higher real sector growth.

\footnotetext{
${ }^{1}$ Most of the studies only partially confirm the part of the test that indicates the causality between financial development and economic growth: Thornton (1996), Demetriades and Hussein (1996), Habibullah (1999), Arestis and Demetriades (1999), Eita and Jordaan (2007), Esso (2010), Hassan, Sanchez, and Yu (2011), Rachdi and Mbarek (2011) Hsueh, Hu, and Tu (2013).
} 
Benczúr, Karagiannis, and Kvedaras (2018) investigate countries that recorded higher income (i.e. OECD, EU, and EMU) and examine effect of domestic private finance structure on (non-linearly), economic growth. The results show that non-linear, hump-shaped finance affects economic growth and is important for controlling financing composition as far as the sources (bank credit, debt securities, stock market) and the recipients of finances (households, non-financial and financial corporations), or both.

Chinese firms' having higher top ten shareholder ratios or firms that are older perform in time off the financial crisis and better in the crisis period (Lee, Chen, \& Ning, 2017).

Asteriou and Spanos (2018) analyzed the relationship between financial development and economic growth during the recent financial crisis faced by 26 European Union countries over the period 1990-2016. Both the period before and after they investigated the crisis in the empirical research. The results present that financial development played a significant role in increasing economic growth before the crisis, while afterwards, it was a factor that hampered economic activity. It reveals that between 2008 and 2009, depositors enjoyed protection and it promoted stability of the financial system thanks to the capital adequacy of banks.

Durusu-Ciftci, Serdar Ispir, and Yetkiner (2017) applied the augmented Mean Group (AMG) and Common-Correlated Effects (CCE) estimators to investigate on how financial development may affect economic growth. The research concerned 40 countries over the period 1989-2011 and showed that credit and stock market developments have positive longstanding effects on steady GDP per capita. The results suggest that in the majority's case of examined countries, financial development was an important component for economic growth.

Bahadir and Valev (2017) examined convergence for household and business credit in 30 European countries for the period 1995-2013. The results lead to a conclusion stating that the benefits of financial convergence for economic growth may be restrict as much of the convergence occurred in terms of household credit.

\section{Finance structure (bank lending) in Croatia 1990-2018}

Bank lending activity in Croatia since 1990 was strong. Because of privatization and transition errors, war, and inherited macroeconomic instabilities, it focused monetary policy on inflation and exchange targeting policy. Under such conditions (strict monetary policy), foreign denominated loans exploded beyond domestic currency loans (see Table 1). During the transition period, Croatia registered the highest share (in total loans) of foreign currency denominated loans amongst transitional countries. From Table 1 we can see that share was about $70 \%$ dropping to $66 \%$ in 2016 due to the conversion of Swiss francs (CHF) loans to EUR and national currency denominated loans. The large share of foreign currency denominated loans affected the structure of the bank lending benefiting households (mortgages) lending.

Table 1. Loans in foreign currency (\% of total credits) 2012-2016 in Croatia (source: CEE Banking Sector Report, 2017)

\begin{tabular}{|c|c|c|c|c|c|}
\hline Country & 2012 & 2013 & 2014 & 2015 & 2016 \\
\hline Croatia & 75 & 74 & 74 & 71 & 66 \\
\hline
\end{tabular}




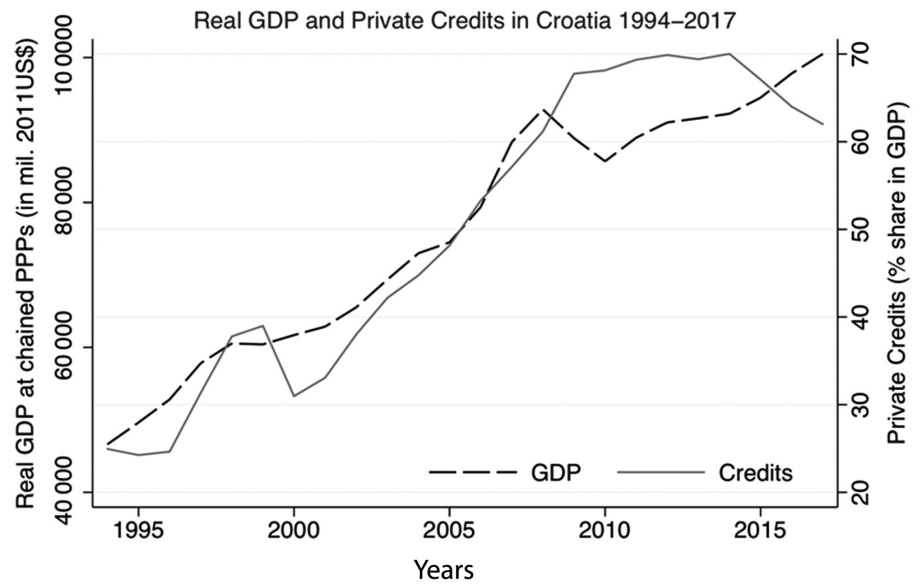

Figure 1. Output and Lending Dynamics in Croatia 1994-2017 (source: authors' calculation)

Figure 1 shows the dynamics between the output (real GDP) and private credits in Croatia from 1994. We can observe a strong correlation disrupted by the business cycles in 1998 and 2008. During output expansion banks' lending rises and declines in time of crisis. It registered high de-leveraging during the crisis of 2008. This is normal since Croatia experienced the longest cycle in the EU with 6 years decline and stagnation in output. Negative expectations of economic agents (government, households and firms) discouraged future borrowing.

This is visible from the Figure 2.

We can see from the Figure 2 that loans to households dominate over the loans to private firms. Loans to households range from 39\% share in the GDP in 2012 to $34 \%$ in 2016 . A strong decline because of de-leveraging since 2012 is visible in the loan to households (decline of five percentage points). Over the same period, loans to private firms also felt from $26.2 \%$ in 2012 to $23 \%$ in 2016 . De-leveraging is stronger in households' loans in relation to

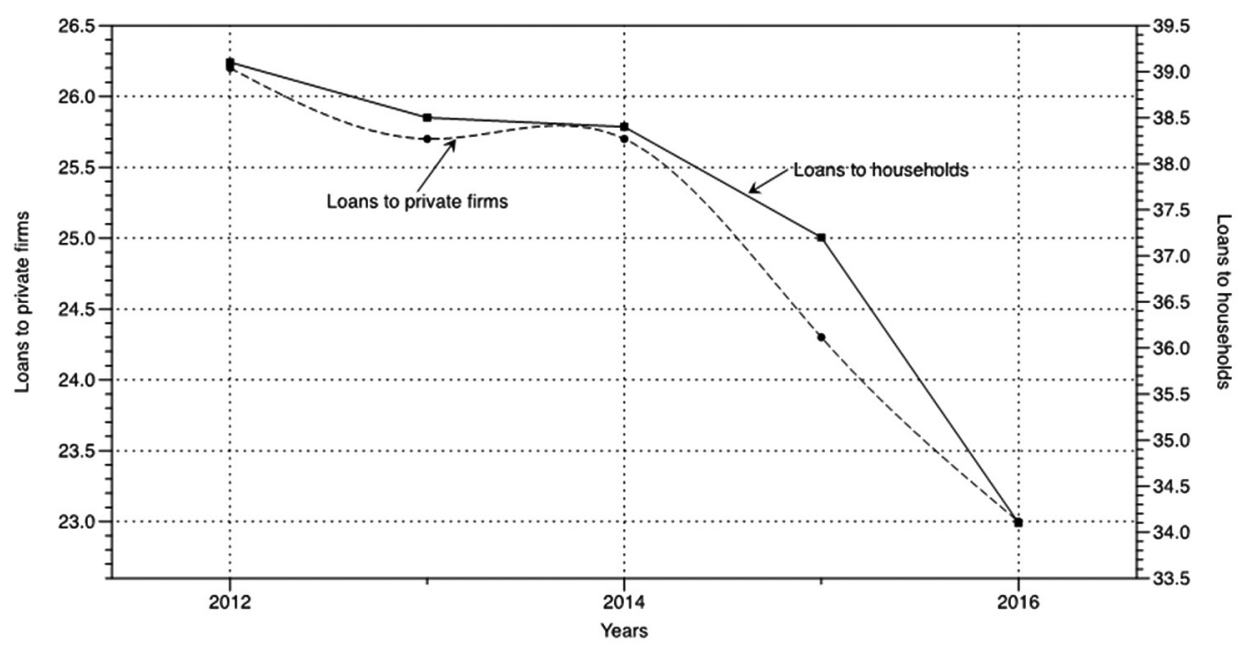

Figure 2. Loans to Households and Private Enterprises (\% of GDP) 2012-2016

(source: CEE Banking Sector Report, 2017) 
loans to private firms. The reason lies in personal consumption sharp decline and real wages drop during the six-year economic cycle. Income crisis economic tax introduced in 2009 over a one-year period. Fiscal consolidation and fiscal austerity policies prolonged the crisis resulting in large mortgages decline affecting credit structures of the banking sector. Figure 3 shows the credit structure in Croatia during 1990-2017.

Figure 3 shows the credit structure (\% share in total loans) by sectors, households, and firms. Loans to private firms dominated during the phase of banks privatization (1993-2000). After the banks' privatization phase, with foreign banks (five banks) getting control over $75 \%$ share of total banks market assets. Foreign banks with the largest share on the markets switched from lending private firms to mortgages and consumption loans offered to households. Credit expansions to households started after 2000 peaked in 2005 and continued until 2009. From the Figure 3, we can see that loans to household peak in 2005 with 58\% of the total loans. Because of the 2008 crisis, loans to households dropped to $43 \%$ of the total loans. However, the drop from 2009 stopped in 2015 and thereafter rose to reach in 2017 previous peak's level of $57 \%$ in 2009 . Banks' lending to private firms dropped after privatization of the financial system. Total lending to private firms shrank from $70 \%$ share in total loans (in 1995) to $40 \%$ in 2003. Foreign commercial banks moved from risky lending to small and medium enterprises (SME) to mortgage and consumers loans backed up by significant collateral. Limited financial lending to SME in Croatia slowed potential GDP in the long run. Rising personal consumption financed by mortgage and consumer credits boost real GDP growth in Croatia. Output in Croatia highly depends on the bank lending. Financial development in Croatia is conducive for economic growth. The financial crisis episode of 2008 back up this hypothesis. Figure 3 shows lending to households and private firms dropped until 2015. Driven by bank lending to households after 2015, output level (real GDP) revived proving "finance-led growth hypothesis" or the "supply-leading hypothesis" holds for Croatia. Following this data-driven hypothesis for Croatia we develop an econometric model to fit the data and explain finance-led growth.

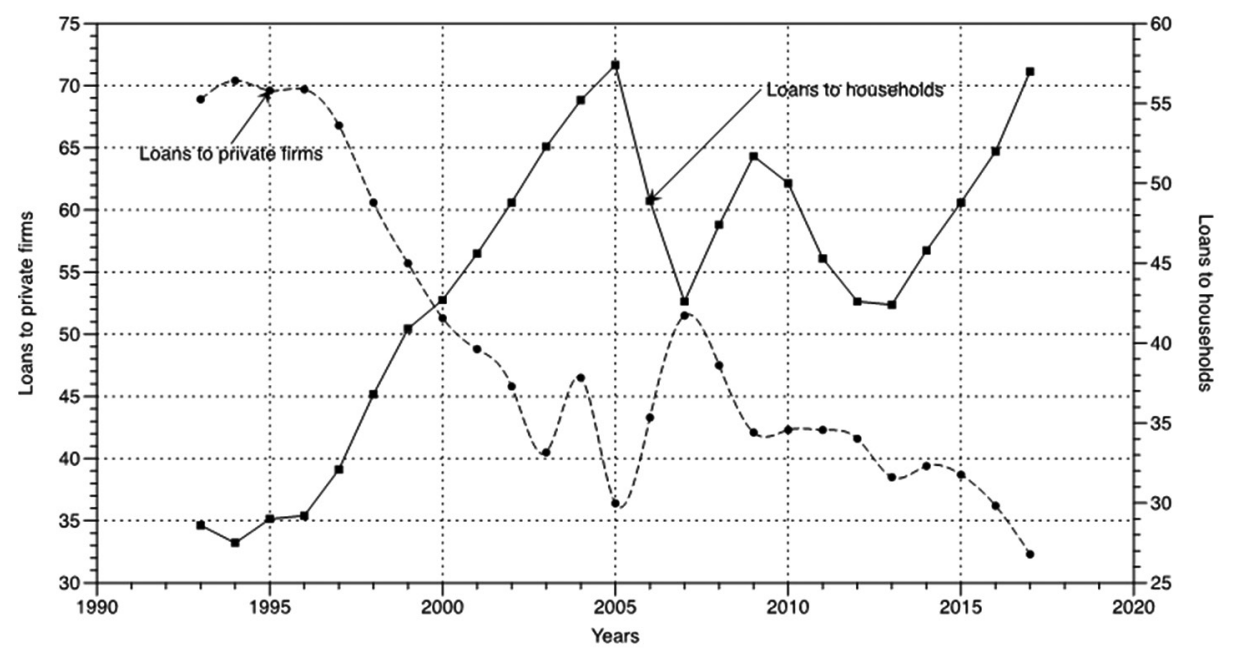

Figure 3. Credit structure (\% share in total loans) in Croatia 1990-2017 (source: Croatian National Bank Statistical Database (www.hnb.hr)) 


\section{Data and methods}

To analyze the finance-led growth link and find evidence to support or disprove the "supplyleading" hypothesis in Croatia we use time series analysis (Vector autoregression and vector error correction). We use data from 1990 to 2017 on real GDP, the share of households' credits in total private credits, the share of private firms' credits in total private credits, human capital stock, total factor productivity, KOF globalization index, and dummy variables for war 1991-1995 and economic crisis 2008. Variables used in the analysis below:

IGDP = logarithm of real GDP at constant national prices (in mil. 2011US\$) - Penn World Table 9.1.

ICAP = logarithm of capital stock at constant national prices (in mil. 2011US\$) - Penn World Table 9.1.

IHUMAN = logarithm of Index of human capital per person, based on years of schooling and returns to education - Penn World Table 9.1.

ITFP $=$ logarithm of total factor productivity at constant national prices $(2011=1)-$ Penn World Table 9.1.

IGLOB = logarithm of KOF index of globalization - Gygli, Haelg, and Sturm (2018).

IHOUSEHOLDS = logarithm of households' credit share in total credits (in \%) - Croatian national bank database (www.hnb.hr).

IFIRMS = logarithm of firms' credit share in total credits (in \%) - Croatian national bank database (www.hnb.hr). We use annual data transformed using standard frequency conversion approach (low to high - quadratic match average in Eviews 10). The data are from several databases: Penn World Table 9.1 (Feenstra, Inklaar, \& Timmer, 2015), World Bank, World Bank Indicators Database (Savina, Haelg, \& Sturm, 2018), Financial development and structure dataset (Beck, Demirguc-Kunt, \& Levine, 2000, 2010), (Cihák, Demirgüç-Kunt, Feyen, \& Levine, 2012), Global financial development database (Cihák et al., 2012, Léon, 2018), WIIW annual database.

Table 2. Unit root test results (source: authors' calculation)

\begin{tabular}{|l|c|c|c|c|c|c|}
\hline \multirow{2}{*}{ Series } & $\begin{array}{c}\text { ADF } \\
\text { (trend and } \\
\text { intercept) }\end{array}$ & $\begin{array}{c}\text { ADF } \\
\text { (trend and } \\
\text { intercept) }\end{array}$ & $\begin{array}{c}\text { PP } \\
\text { (trend and } \\
\text { intercept) }\end{array}$ & $\begin{array}{c}\text { PP } \\
\text { (trend and } \\
\text { intercept) }\end{array}$ & $\begin{array}{c}\text { KPSS } \\
\text { (trend and } \\
\text { intercept) }\end{array}$ & $\begin{array}{c}\text { KPSS } \\
\text { (trend and } \\
\text { intercept) }\end{array}$ \\
\hline Level & $\begin{array}{c}\text { First } \\
\text { difference }\end{array}$ & Level & $\begin{array}{c}\text { First } \\
\text { difference }\end{array}$ & Level & $\begin{array}{c}\text { First } \\
\text { difference }\end{array}$ \\
\hline GDP & -1.25 & -3.94 & -0.51 & -4.03 & 1.09 & 0.3 \\
\hline HUP & -0.33 & -3.5 & 0.16 & -3.46 & 1.14 & 0.26 \\
\hline TFP & 0.19 & -2.44 & 1.96 & -4.44 & 1.14 & 0.51 \\
\hline HOUSEHOLDS & -0.11 & -3.74 & 0.36 & -3.73 & 1.12 & 0.3 \\
\hline FIRMS & -1.92 & -2.27 & -1.23 & -3.64 & 0.74 & 0.12 \\
\hline
\end{tabular}

Note: ${ }^{* * *},{ }^{* *}$ and ${ }^{*}$ denote significance at $1 \%, 5 \%$ and $10 \%$. We selected maximum lag length for the test based on the lag length criteria (lag length test) considering loss in the degrees of freedom. 
We test for the stationarity in the series using standard unit root test; (ADF) - (Dickey \& Fuller, 1979), (PP) - (Phillips \& Perron, 1988), and (KPSS) - (Kwiatkowski, Phillips, Schmidt, \& Shin, 1992).

From Table 2 we can see that the battery of standard unit root test results show series to be I(1). We check for a cointegration relationship between the selected variables and apply the Johansen cointegration test (Johansen, 1991, 1995; Johansen \& Juselius, 1990). Using standard VAR (vector autoregression) lag selection procedure based on (AIC) Akaike's (Akaike, 1974) and (SIC) - Schwarz's Information Criteria (Schwarz, 1978). We use optimal lag selection process through Ljung-Box Q statistics (Ljung \& Box, 1978) increasing one lag until no autocorrelation issue exist (optimum lag). For the Lag selection we use (AIC) and (SIC) in the Wald Lag exclusion test (Lütkepohl, 2005). Both tests, (Ljung \& Box, 1978) and Wald test (Lütkepohl, 2005) select the lag length of 1 as the optimum lag length in the VECM. Table 3 show the results for the Johansen and Juselius (1990) cointegration test.

Table 3. Johansen-Juselius Cointegration test results with (IFIRMS) (source: authors' calculation)

\begin{tabular}{|c|c|c|c|c|}
\hline Hypothesized & Trace & Max-Eigen & Critical Values (5\%) & \\
\hline No. of CE(s) & Statistic & Statistic & Trace & Max-Eigen \\
\hline $\mathrm{r}=0^{*}$ & 117.33 & 52.77 & 69.82 & 33.88 \\
\hline $\mathrm{r} \leq 1^{*}$ & 64.56 & 35.44 & 47.86 & 27.58 \\
\hline $\mathrm{r} \leq 2$ & 29.12 & 18.76 & 29.8 & 21.13 \\
\hline $\mathrm{r} \leq 3$ & 10.36 & 9.66 & 15.49 & 14.26 \\
\hline $\mathrm{r} \leq 4$ & 0.7 & 0.7 & 3.84 & 3.84 \\
\hline
\end{tabular}

Trace test and Max-Eigen test (see Tables 3 and 4) reject the null hypothesis of no cointegrating relations $(\mathrm{r}=0)$ and one cointegrating relation $(\mathrm{r} \leq 1)$ at $5 \%$ significance level. Trace and Max-Eigen test do not reject the null of two (2) cointegrating equation at $5 \%$ significance level finding two long-run cointegration relationship between IGDP and its determinants in the equation (1). This holds for the equation with IHOUSEHOLDS and IFIRMS series. We find VECM equation can estimate the impact of the households' and firms' credits on output in Croatia.

Table 4. Johansen-Juselius Cointegration test results with (lHOUSEHOLDS) (source: authors' calculation)

\begin{tabular}{|c|c|c|c|c|}
\hline Hypothesized & Trace & Max-Eigen & Critical Values (5\%) & \\
\hline No. of CE(s) & Statistic & Statistic & Trace & Max-Eigen \\
\hline $\mathrm{r}=0^{*}$ & 114.6 & 60.93 & 69.82 & 33.88 \\
\hline $\mathrm{r} \leq 1^{*}$ & 53.67 & 36.81 & 47.86 & 27.58 \\
\hline $\mathrm{r} \leq 2$ & 16.85 & 7.92 & 29.8 & 21.13 \\
\hline $\mathrm{r} \leq 3$ & 8.93 & 5.18 & 15.49 & 14.26 \\
\hline $\mathrm{r} \leq 4$ & 3.76 & 3.76 & 3.84 & 3.84 \\
\hline
\end{tabular}


Following the unit root test results and cointegration test result, we set two VECM equations to analyze the credit structure impact on output in Croatia during 1990-2017:

$$
\begin{gathered}
l G D P=\beta_{0}+\beta_{1} l C A P_{t}+\beta_{2} \text { HUMAN }_{t}+\beta_{3} \text { GLOBAL }+\beta_{4} l \text { HOUSEHOLDS }+\beta_{5} \text { WAR }+\beta_{6} \text { CRISIS }+e_{t} \\
l G D P=\beta_{0}+\beta_{1} l C A P_{t}+\beta_{2} \text { HUMAN }_{t}+\beta_{3} G L O B A L+\beta_{4} l \text { lFIRMS }+\beta_{5} \text { WAR }+\beta_{6} \text { CRISIS }+e_{t} .
\end{gathered}
$$

\section{Results and discussion}

Estimated VECM model (long run equation) assessing the impact of firms' lending on the output with two dummy variables (WAR taking 1 from 1991-1995 and CRISIS from 2009-2015):

$$
l G D P_{t-1}=8.806963+3.830096 \text { lHUMAN }_{t-1}+0.392111 \text { lFIRMS }_{t-1}+0.368097 \text { lGLOBAL }_{t-1} . \text { (3) }
$$

All variables in the equation (3) are positive and significant at 5\% significance level. Estimated VECM show the long run equilibrium relationship between real GDP, human capital stock, level of the country's exposure to globalization and bank lending to firms. Variables are in the logarithm form, we can interpret associated long-run parameters as partial elasticity coefficients. We can observe that a $1 \%$ increase in the human capital stock (HUMAN) with a $1 \%$ increase in the human capital stock leading to $3.83 \%$ increase in the real GDP. Increase in the KOF index (Global) results in a real GDP increase of $0.36 \%$. The lending activity of the financial sector measured by the share of firms' credits in total credits has a positive impact on the real output. An increase in the bank lending to firms by $1 \%$ leads to a growth in the real GDP by $0.39 \%$.

To estimate the link between firms' lending and output growth, we use the Granger causality test (Granger, 1969). We present Granger causality test results together with the speed

\begin{tabular}{|c|c|c|c|c|c|c|}
\hline \multicolumn{7}{|c|}{ Independent variable } \\
\hline \multirow{2}{*}{$\begin{array}{c}\text { Dependent } \\
\text { variable }\end{array}$} & \multicolumn{5}{|c|}{ F statistics of lagged 1st differenced term [p-value] } & \multirow{2}{*}{$\begin{array}{c}E C T \\
\text { coefficien } \\
\text { (t-ratio) }\end{array}$} \\
\hline & $\triangle l G D P$ & $\triangle l C A P$ & $\triangle l H U M A N$ & $\triangle l F I R M S$ & $\triangle l G L O B A L$ & \\
\hline \multirow{2}{*}{$\triangle l G D P$} & \multirow{2}{*}{-} & 1.8 & 4.43 & 2.62 & 4.28 & -0.09 \\
\hline & & [0.17] & {$[0.01]^{* * *}$} & {$[0.08]^{*}$} & {$[0.02]^{* *}$} & $(-4.63)$ \\
\hline \multirow{2}{*}{$\triangle l C A P$} & 1.07 & \multirow{2}{*}{-} & 3.63 & 5.23 & 3.03 & -0.0 \\
\hline & {$[0.35]$} & & {$[0.03]^{* *}$} & {$[0.01]^{\star * *}$} & {$[0.05]^{* *}$} & $(-0.11)$ \\
\hline \multirow{2}{*}{$\triangle l H U M A N$} & 1.17 & 1.98 & \multirow{2}{*}{ - } & 1.44 & 1.86 & 0.0 \\
\hline & {$[0.31]$} & {$[0.14]$} & & {$[0.24]$} & {$[0.16]$} & $(-2.02)$ \\
\hline \multirow{2}{*}{$\Delta l F I R M S$} & $3.28^{\star \star}$ & 1.75 & 1.82 & \multirow{2}{*}{ - } & 4.51 & -0.03 \\
\hline & {$[0.04]$} & {$[0.18]$} & {$[0.17]$} & & {$[0.01]^{\star * *}$} & $(-0.39)$ \\
\hline \multirow{2}{*}{$\triangle l G L O B A L$} & 1.26 & 0.97 & 0.16 & 0.83 & \multirow{2}{*}{ - } & -0.01 \\
\hline & {$[0.29]$} & {$[0.38]$} & {$[0.85]$} & {$[0.44]$} & & $(-0.8)$ \\
\hline
\end{tabular}
of adjustment coefficients in Table 5.

Table 5. Granger causality test results with (IFIRMS) (source: authors' calculation)

Note: ${ }^{* *}$ and ${ }^{* *}$ denotes significant at $1 \%$ and $5 \%$ significance level, respectively. The number in the parenthesis $(\ldots)$ denote as $\mathrm{t}$-statistic and in the squared brackets $[. .$.$] represent a \mathrm{p}$-value. 
Adjustment in the real GDP is achieved by the change in the past real GDP values and human capital stock. Granger causality test results show a bidirectional causality running between credits to firms and output. We find evidence to support both demand and supply-leading theory. We find the credit structure to be an important factor of growth in Croatia. An $1 \%$ increase in financial lending to firms (IFIRMS) results in a real GDP increase of $0.39 \%$.

Variance decomposition (see Figure 4) shows the impact of variations in capital stock, human capital stock, credits to firms and globalization on the real GDP.

From the Figure 4, we can see the previous level of lGDP, credits to firms and world globalization influence most of the output dynamics in Croatia. The results support the supplyleading hypothesis and small open economies theory, in particular for the EU members countries (small opened economies as Croatia).

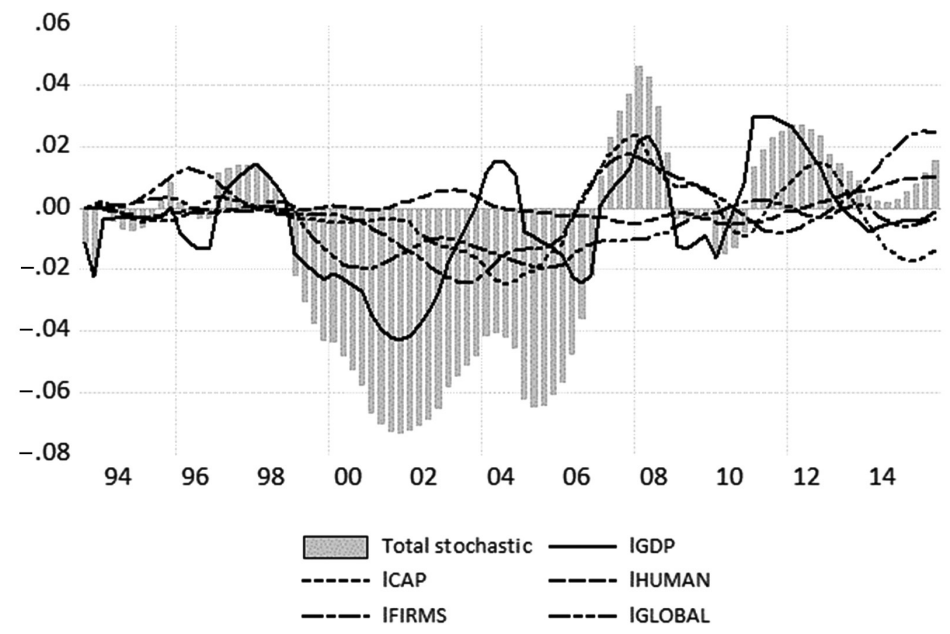

Figure 4. Variance Decomposition of lGDP (with lFIRMS) (source: authors' calculation)

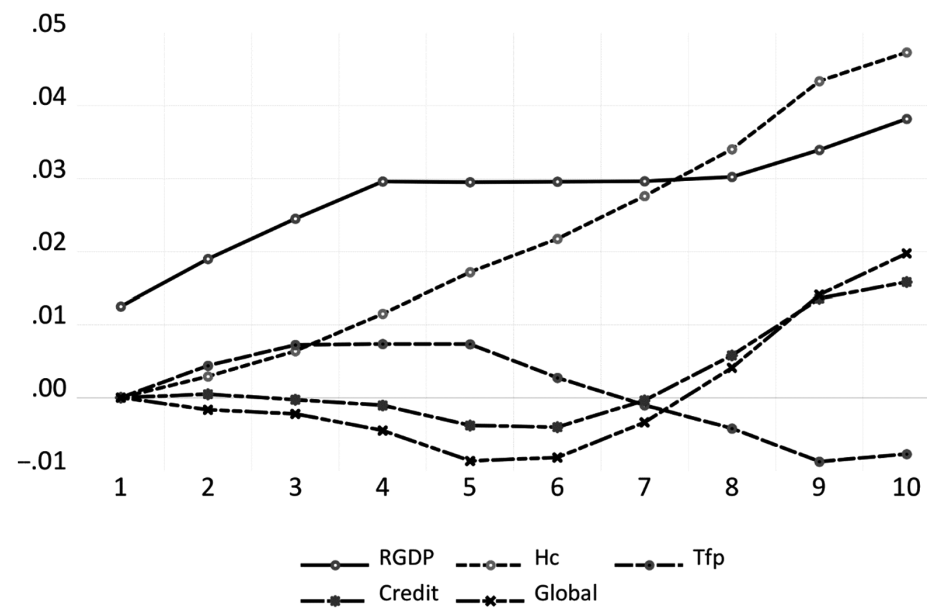

Figure 5. Response of RGDP to Innovation (with lFIRMS) (source: authors' calculation) 
Figure 5 shows shocks in real GDP, human capital, bank lending to firms and globalization have a long-term positive impact on output. Change in the human capital stock has a positive impact on real GDP and show long memory pattern. A shock to lFIRMS has a stagnating effect on output in the short run. In the long-run, lending to firms' show positive and long-lasting effects on the real GDP with the effect continuing to persist beyond the 10th quarter. Globalization shows opposite dynamics since firms don't use bank lending to improve capital/output ratio resulting in a rise in competitive export and share in the world trade. Instead, a majority of the firms use loans for improving liquidity position in the short run.

Following we estimate VECM model analyzing the impact of households' lending on the output with two dummy variables (WAR taking 1 from 1991-1995 and CRISIS from 2009-2015):

$$
\begin{aligned}
l G D P_{t-1}= & 9.425365+2.772076 \text { lHUMAN }_{t-1}+0.445583 \text { lHOUSEHOLDS }_{t-1}+ \\
& 0.766816 \text { lGLOBAL }_{t-1} .
\end{aligned}
$$

The long-run equation shows an increase in the human capital stock by $1 \%$ rise in real GDP by $2.77 \%$ while $1 \%$ increase in the KOF index increases real GDP by $0.77 \%$. In the long run, households' lending positively influences the real GDP. A $1 \%$ increase in the households lending results in $0.44 \%$ growth in output (real GDP). Households' lending shows a stronger impact on real output in Croatia us expect what since around $70 \%$ of the total credits were in the form of private loans to households.

Table 6 shows the result of the Granger causality test.

\begin{tabular}{|c|c|c|c|c|c|c|}
\hline \multicolumn{7}{|c|}{ Independent variable } \\
\hline \multirow{2}{*}{$\begin{array}{l}\text { Dependent } \\
\text { variable }\end{array}$} & \multicolumn{5}{|c|}{ F statistics of lagged 1st differenced term [p-value] } & \multirow{2}{*}{$\begin{array}{c}\text { ECT } \\
\text { coefficient } \\
\text { (t-ratio) }\end{array}$} \\
\hline & $\triangle l G D P$ & $\triangle l C A P$ & $\triangle l H U M A N$ & $\triangle H O U S E H O L D S$ & $\triangle l G L O B A L$ & \\
\hline \multirow{2}{*}{$\triangle l G D P$} & \multirow{2}{*}{-} & 1.8 & 4.43 & 3.21 & 4.28 & -0.07 \\
\hline & & {$[0.17]$} & {$[0.01]$} & {$[0.05]$} & {$[0.02]$} & $(-2.82)$ \\
\hline \multirow{2}{*}{$\triangle l C A P$} & 1.07 & \multirow{2}{*}{-} & 3.63 & 4.65 & 3.03 & 0.09 \\
\hline & {$[0.35]$} & & {$[0.03]$} & {$[0.01]$} & {$[0.05]$} & $(-1.54)$ \\
\hline \multirow{2}{*}{$\triangle l H U M A N$} & 1.17 & 1.98 & \multirow{2}{*}{-} & 1.56 & 1.86 & -0.0 \\
\hline & {$[0.31]$} & {$[0.14]$} & & {$[0.22]$} & {$[0.16]$} & $(-0.35)$ \\
\hline \multirow{2}{*}{$\triangle H O U S E H O L D S$} & 2.77 & 0.5 & 1.38 & \multirow{2}{*}{-} & 1.83 & 0.01 \\
\hline & {$[0.07]$} & {$[0.61]$} & {$[0.26]$} & & {$[0.17]$} & {$[0.18]$} \\
\hline \multirow{2}{*}{$\triangle l G L O B A L$} & 1.26 & 0.97 & 0.16 & 1.36 & & 0.09 \\
\hline & [0.29] & {$[0.97]$} & {$[0.85]$} & {$[0.26]$} & & [3.93] \\
\hline
\end{tabular}

Table 6. Granger causality test results (with lHOUSEHOLDS) (source: authors' calculation)

Note: ${ }^{* *}$ and ${ }^{* *}$ denotes significant at $1 \%$ and $5 \%$ significance level. The number in the parenthesis (...) denote as t-statistic and in the squared brackets [...] represent a p-value. 
Adjustments in the real GDP happens by the change in the past real GDP values exports (openness to world trade). Human capital can gross capital stock do not show important change properties. Granger causality test results (Table 6) show a bidirectional causality running between households' loans (lHOUSEHOLDS) and output (IGDP). Finance-growth nexus shows bi-directional causality supporting supply-leading and demand-leading theory. Increase in households' lending increase total output and rising output leads to increasing financial demand and further financial development.

Variance decomposition (see Figure 6) shows the impact of variations in human capital stock, gross capital stock, globalization and households' loans on the real GDP.

Figure 7 shows most of the changes in the real GDP dynamics is due to changes in the lagged GDP values and globalization. Sensitivity to world trade and the crisis has a strong impact on the economic conditions of small and open economies such as Croatia. A variance

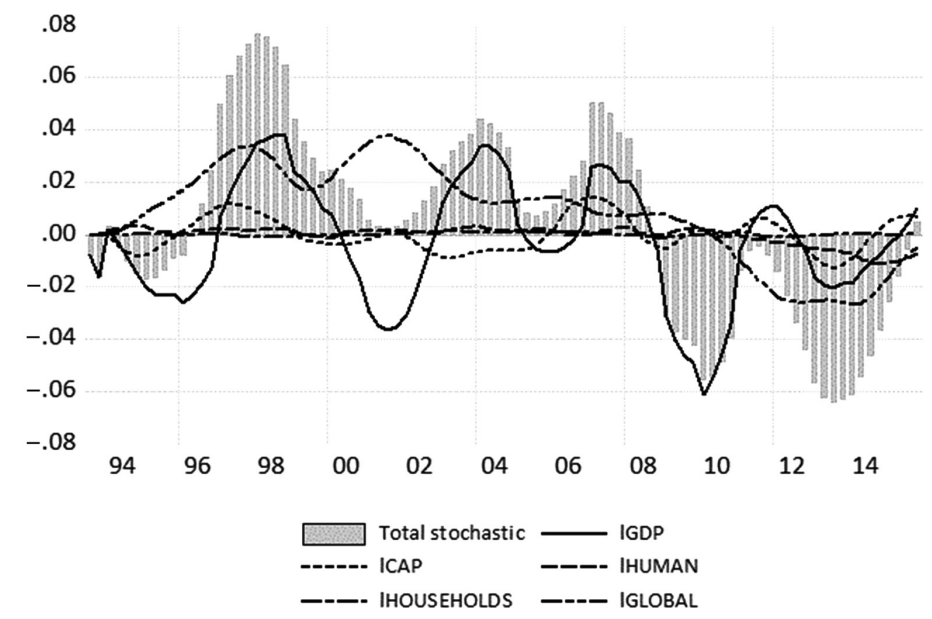

Figure 6. Variance decomposition of lGDP (with lFIRMS) (source: authors' calculation)

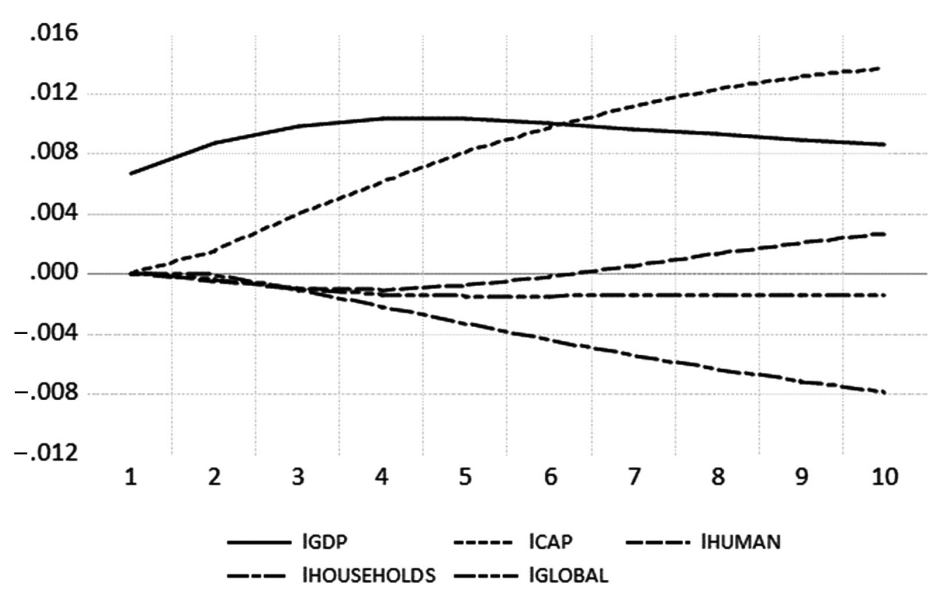

Figure 7. Response of RGDP to innovation (with lFIRMS) (source: authors' calculation) 
decomposition for the real GDP shows human capital stock, gross capital stock, and households' lending has a limited effect on the output dynamics in Croatia from 1990 to 2018.

Shocks in real GDP has a positive, persistent impact on the real GDP (Figure 7). Effects of the shock in the real GDP is not dying out, in the long run, showing persistence. Exogenous shock in the capital stock also lasts over ten quarters. Shock in household lending (lHOUSEHOLDS) negatively influences the real GDP up to ten quarters turning negative after three quarters. Globalization negatively influences the GDP dynamics in Croatia over the long run showing long memory properties (persistence). Shock in human capital stock neutrally influences the real GDP in the short run (two quarters) turning positive after six quarters. Our study result are important for CEE and transitional and developing economies policy makers to set up adequate debt policy and consequently investment and growth policies as well. The example of Croatia shows that after entering European Union lending policy of the financial sector change in favor of firms' lending instead of households. This in turn stimulate economic growth in recent time for the Croatian economy.

\section{Conclusions}

The nexus between financial development and economic growth depends on monetary policy tightness which determines the private credit structure as this study show. The future studies in the finance and economic growth link should consider the relationship between the two depends on the proxy variable used in the empirical studies. Empirical studies using total private credit share in the GDP show a diverse (positive/negative) impact on economic growth. The robustness of the model used in the empirical studies is low. Panel country studies, and individual country studies, show the finance-growth relationship change from positive to negative affecting results robustness. This study shows that more robust and valid results are obtained when using the credit structure as a proxy variable for finance. Results (at least for Croatia) show that loans to firms versus loans to household have a different impact on economic growth. Loans to households are more sensitive to economic crises and have a negative long-term impact on economic growth. Credit to firms has a positive impact on economic growth, in the long run, increasing export and openness leading to a rise in investments and employment. We find empirical evidence to support both supply-leading and demandfollowing theory. Bi-directional causality between private loans to firms/households and economic growth exists using Granger causality test. Private loans to firms and households have a positive impact on economic growth in Croatia. Rising growth leads to more leverage boosting banks' lending to firms and households. VECM modeling techniques prove to be reliant when investigating the finance-growth link. However, the residual shows the potential existence of long-memory in economic growth and banks' lending. Future research should explore the possibility to use fractional integration modeling to study the finance-growth link. More robust results could be obtained if long-memory property of the series is used in the analysis. Study results show diversified banks' lending policy have a different impact on economic growth. In the short run, loans to households increase personal consumption and economic growth. In the long run, however, the impact turns negative if affected by economic shocks. Lending to firms in the short run does not have a significant impact on economic 
growth. In the long run, lending to firms increase investments and capital stock leading to more significant economic growth. Lending to the firms are also less sensitive to economic shocks in relation to the loans to households. Study results are limited to a single county and should be checked on a larger sample and using different econometric techniques (fractional integration). Policy makers can find important practical information when setting up efficient economic policy favoring lending to the firms' and investments policies in equipment, research and development instead of structural investments.

\section{Acknowledgements}

We are grateful anonymous reviewers for their insightful recommendations.

\section{Author contributions}

Marinko Škare carried on the econometric study in the paper. Dean Sinković conceived the study. Małgorzata Porada-Rochoń were responsible for data collection, theoretical background and data analysis.

\section{Disclosure statement}

Authors don't have any competing financial, professional, or personal interests from other parties.

\section{References}

Acaravci, A., Ozturk, I., \& Kakilli Acaravci, S. (2007). Finance growth nexus: evidence from Turkey. International Research Journal of Finance and Economics, 11, 30-40.

Akaike, H. (1974). A new look at the statistical model identification. IEEE Transactions on Automatic Control, 19(6), 716-723. https://doi.org/10.1109/tac.1974.1100705

Arestis, P., \& Demetriades, P. (1999). Finance and growth: institutional considerations, financial policies and causality. Zagreb International Review of Economics \& Business, 2(1), 37-62.

Arestis, P., Demetriades, P. O., \& Luintel, K. B. (2001). Financial development and economic growth: the role of stock markets. Journal of Money, Credit and Banking, 33(1), 16-41. https://doi.org/10.2307/2673870

Asteriou, D., \& Spanos, K. (2018). The relationship between financial development and economic growth during the recent crisis: evidence from the EU. Finance Research Letters (in press). https://doi.org/10.1016/j.frl.2018.05.011

Bahadir, B., \& Valev, N. (2017). Catching up or drifting apart: Convergence of household and business credit in Europe. International Review of Economics \& Finance, 47, 101-114. https://doi.org/10.1016/j.iref.2016.10.006

Beck, T., \& Levine, R. (2004). Stock markets, banks, and growth: Panel evidence. Journal of Banking \& Finance, 28(3), 423-442. https://doi.org/10.1016/S0378-4266(02)00408-9

Beck, T., Demirguc-Kunt, A., \& Levine, R. (2000). A new database on the structure and development of the financial sector. The World Bank Economic Review, 14(3), 597-605.

https://doi.org/10.1093/wber/14.3.597 
Beck, T., Demirgüç-Kunt, A., \& Levine, R. (2010). Financial institutions and markets across countries and over time: the updated financial development and structure database. The World Bank Economic Review, 24(1), 77-92. https://doi.org/10.1093/wber/lhp016

Benczúr, P., Karagiannis, S., \& Kvedaras, V. (2017). Finance and economic growth: financing structure and non-linear impact (JRC Working Papers in Economics and Finance). Luxembourg: Publications Office of the European Union.

Benczúr, P., Karagiannis, S., \& Kvedaras, V. (2018). Finance and economic growth: financing structure and non-linear impact. Journal of Macroeconomics (in press). https://doi.org/10.1016/j.jmacro.2018.08.001

Bojanic, A. N. (2012). The impact of financial development and trade on the economic growth of Bolivia. Journal of Applied Economics, 15(1), 51-70. https://doi.org/10.1016/S1514-0326(12)60003-8

Calderon, C., \& Liu, L. (2003). The direction of causality between financial development and economic growth. Journal of Development Economics, 72(1), 321-334. https://doi.org/10.1016/S0304-3878(03)00079-8

Caporale, G. M., Rault, C., Sova, R., \& Sova, A. (2009). Financial development and economic growth: evidence from ten new EU members (DIW Berlin Discussion Papers No. 940). https://doi.org/10.2139/ssrn.1499786

CEE Banking Sector Report. (2017). Retrieved from https://www.rbinternational.com/eBusiness/01_ template1/829189266947841370-829189148030934104-1334500338675784871-NA-2-EN.html

Chimobi, O. M. (2010). The causal relationship among financial development, trade openness and economic growth in Nigeria. International Journal of Economics and Finance, 2(2), 137-147. https://doi.org/10.5539/ijef.v2n2p137

Christopoulos, D. K., \& Tsionas, E. G. (2004). Financial Development and economic growth: evidence from panel unit root and cointegration tests. Journal of Development Economics, 73(1), 55-74. https://doi.org/10.1016/j.jdeveco.2003.03.002

Cihák, M., Demirgüç-Kunt, A., Feyen, E., \& Levine, R. (2012). Benchmarking financial systems around the world. The World Bank. https://doi.org/10.1596/1813-9450-6175

Darrat, A. F. (1999). Are financial deepening and economic growth causally related? Another look at the evidence. International Economic Journal, 13(3), 19-35. https://doi.org/10.1080/10168739900000002

Demetriades, P. O., \& Hussein, K. A. (1996). Does financial development cause economic growth? Time-series evidence from 16 countries. Journal of Development Economics, 51(2), 387-411. https://doi.org/10.1016/S0304-3878(96)00421-X

Demirguc-Kunt, A., Detragiache, E., \& Merrouche, O. (2013). Bank capital: lessons from the financial crisis. Journal of Money, Credit and Banking, 45, 1147-1164. https://doi.org/10.1111/jmcb.12047

Dritsakis, N., \& Adamopoulos, A. (2004). Financial development and economic growth in Greece: An empirical investigation with Granger causality analysis. International Economic Journal, 18(4), 547559. https://doi.org/10.1080/1016873042000299981

Dickey, D. A., \& Fuller, W. A. (1979). Distribution of the estimators for autoregressive time series with a unit root. Journal of the American Statistical Association, 74(366), 427-431. https://doi.org/10.2307/2286348

Durusu-Ciftci, D., Serdar Ispir, M., \& Yetkiner, H. (2017). Financial development and economic growth: some theory and more evidence. Journal of Policy Modeling, 39(2), 290-306. https://doi.org/10.1016/j.jpolmod.2016.08.001

Egbetunde, T., \& Akinlo, A. E. (2015). Financial globalization and economic growth in Sub-Saharan Africa: Evidence from panel cointegration tests. African Development Review, 27(3), 187-198. https://doi.org/10.1111/1467-8268.12140

Eita, J. H., \& Jordaan, A. C. (2010). A causality analysis between financial development and economic growth for Botswana. The African Finance Journal, 12(1), 72-89. 
Enisan, A. A., \& Olufisayo, A. O. (2009). Stock market development and economic growth: evidence from seven Sub-Sahara African countries. Journal of Economics and Business, 61(2), 162-171. https://doi.org/10.1016/j.jeconbus.2008.05.001

Esso, L. J. (2010). Cointegrating and causal relationship between financial development and economic growth in ECOWAS countries. Journal of Economics and International Finance, 2(4), 36-48.

Fan, J.-J., Xu, R., Su, C. W., \& Shi, Q.-H. (2017). Demand-following or supply-leading? Trade openness and financial development in China. The Journal of International Trade \& Economic Development, 27(3), 314-332. https://doi.org/10.1080/09638199.2017.1390779

Feenstra, R. C., Inklaar, R., \& Timmer, M. P. (2015). The next generation of the Penn World Table. American Economic Review, 105(10), 3150-3182. https://doi.org/10.1257/aer.20130954

Goldsmith, R. (1969). Financial structure and development. New Haven: Yale University Press.

Gómez-Puig, M., \& Sosvilla-Rivero, S. (2018). Nonfinancial debt and economic growth in euro-area countries. Journal of International Financial Markets Institutions and Money, 56, 17-37. https://doi.org/10.1016/j.intfin.2018.03.005

Granger, C. (1969). Investigating causal relations by econometric models and cross-spectral methods. Econometrica, 37(3), 424-438. https://doi.org/10.2307/1912791

Gygli, S., Haelg, F., \& Sturm, J.-E. (2018). The KOF Globalisation Index - revisited (KOF Working Paper No. 439). Retrieved from https://www.ethz.ch/content/dam/ethz/special-interest/dual/kof-dam/ documents/Globalization/2018/KOF_Globalisation\%20Index_Revisited.pdf

Habibullah, M. S. (1999). Financial development and economic growth in Asian countries: testing the financial-led growth hypothesis. Savings and Development, 23(3), 279-291.

Habibullah, M. S., \& Eng, Y-K. (2006). Does financial development cause economic growth? A panel data dynamic analysis for the Asian developing countries. Journal of the Asia Pacific Economy, 11(4), 377-393. https://doi.org/10.1080/13547860600923585

Hassan, M. K., Sanchez, B., \& Yu, J-S. (2011). Financial development and economic growth: new evidence from panel data. The Quarterly Review of Economics and Finance, 51(1), 88-104. https://doi.org/10.1016/j.qref.2010.09.001

Hsueh, S-J., Hu, Y-H., \& Tu, C-H. (2013). Economic growth and financial development in Asian countries: a bootstrap panel Granger causality analysis. Economic Modelling, 32, 294-301. https://doi.org/10.1016/j.econmod.2013.02.027

Ibrahim, M., \& Alagidede, P. (2018). Effect of financial development on economic growth in sub-Saharan Africa. Journal of Policy Modeling, 40(6), 1104-1125. https://doi.org/10.1016/j.jpolmod.2018.08.001

Johansen, S. (1991). Estimation and hypothesis testing of cointegration vectors in Gaussian vector autoregressive models. Econometrica, 59(6), 1551-1580. https://doi.org/10.2307/2938278

Johansen, S. (1995). Likelihood-based inference in cointegrated vector autoregressive models. Oxford University Press. https://doi.org/10.1093/0198774508.001.0001

Johansen, S., \& Juselius, K. (1990). Maximum likelihood estimation and inference on cointegration with applications to the demand for money. Oxford Bulletin of Economics and Statistics, 52(2), 169-210. https://doi.org/10.1111/j.1468-0084.1990.mp52002003.x

Kilimani, N. (2009, March). The link between financial development and economic growth in Uganda: a causality test. Paper presented at the Centre for Study of African Economies (CSAE) Conference (pp. 22-24).

King, R. G., \& Levine, R. (1993a). Finance and growth: Schumpeter might be right. The Quarterly Journal of Economics, 108(3), 717-737. https://doi.org/10.2307/2118406

King, R. G., \& Levine, R. (1993b). Finance, entrepreneurship and growth. Journal of Monetary Economics, 32(3), 513-542. https://doi.org/10.1016/0304-3932(93)90028-E

Kuznets, S. (1955). Economic growth and income inequality. American Economic Review, 45, 1-28. 
Kwiatkowski, D., Phillips, P. C. B., Schmidt, P., \& Shin, Y. (1992). Testing the null hypothesis of stationarity against the alternative of a unit root. Journal of Econometrics, 54(1-3), 159-178. https://doi.org/10.1016/0304-4076(92)90104-Y

Lee, J. (2005). Financial intermediation and economic growth evidence from Canada. Eastern Economics Association, New York.

Lee, C.-C., Chen, M.-P., \& Ning, S.-L. (2017). Why did some firms perform better in the global financial crisis? Economic Research-Ekonomska Istraživanja, 30(1), 1339-1366. https://doi.org/10.1080/1331677X.2017.1355258

Léon, F. (2018). Convergence of credit structure around the world. Economic Modelling, 68, 306-317. https://doi.org/10.1016/j.econmod.2017.07.021

Levine, R. (2005). Finance and growth: theory and evidence. Handbook of Economic Growth, 1, 865-934. https://doi.org/10.1016/S1574-0684(05)01012-9

Levine, R., \& Zervos, S. (1998). Stock markets, banks, and economic growth. The American Economic Review, 88(3), 537-558.

Ljung, G. M., \& Box G. E. P. (1978). On a measure of lack of fit in time series models. Biometrika, 65, 297-303. https://doi.org/10.1093/biomet/65.2.297

McKinnon, R. I. (1973). Money and capital in economic development. Washington, DC, The Brookings Institution.

Patrick, H. T. (1966). Financial development and economic growth in underdeveloped countries. Economic Development and Cultural Change, 14, 174-189. https://doi.org/10.1086/450153

Phillips, P. C. B., \& Perron, P. (1988). Testing for a unit root in time series regression. Biometrika, 75, 335-346. https://doi.org/10.1093/biomet/75.2.335

Rachdi, H., \& Mbarek, H. B. (2011). The causality between financial development and economic growth: panel data cointegration and GMM system approaches. International Journal of Economics and Finance, 3(1), 143-151. https://doi.org/10.5539/ijef.v3n1p143

Ray, S. (2013). Does financial development promote economic growth in India? International Journal of Economic Practices and Theories, 3(3), 140-151.

Savina, G., Haelg, F., \& Sturm, J. E. (2018). The KOF globalisation index - revisited (KOF Working Paper No. 439). Retrieved from https://www.ethz.ch/content/dam/ethz/special-interest/dual/kof-dam/ documents/Globalization/2018/KOF_Globalisation\%20Index_Revisited.pdf

Schumpeter, J. A. (1934). The theory of economic development. Cambridge, MA: Harvard University Press.

Schwarz, G. (1978). Estimating the dimension of a model. The Annals of Statistics, 6(2), 461-464. https://doi.org/10.1214/aos/1176344136

Shaw, E. S. (1973). Financial deepening in economic development. New York: Oxford University Press.

Stolbov, M. (2017). Causality between credit depth and economic growth: evidence from 24 OECD countries. Empirical Economics, 53(2), 493-524. https://doi.org/10.1007/s00181-016-1142-0

Thornton, J. (1996). Financial deepening and economic growth in developing economies. Applied Economics Letters, 3(4), 243-246. https://doi.org/10.1080/758520872

Topcu, E. (2016). Reexamining finance-growth nexus: a new literature survey. Ecoforum, 5, 64-71.

Topcu, M., \& Çoban, S. (2017). Financial development and firm growth in Turkish manufacturing industry: evidence from heterogeneous panel based non-causality test. Economic Research-Ekonomska Istraživanja, 30(1), 1758-1769. https://doi.org/10.1080/1331677X.2017.1383179 